DOI: https://doi.org/10.32839/2304-5809/2020-12-88-32

УДК 336.15

Петик Л.О., Корень Д.О.

Львівський національний університет імені Івана Франка

\title{
МІЖБЮДЖЕТНІ ТРАНСФЕРТИ ЯК СКЛАДОВА МІЖБЮДЖЕТНИХ ВІДНОСИН: СУЧАСНИЙ СТАН ТА ПЕРСПЕКТИВИ РОЗВИТКУ
}

\begin{abstract}
Анотація. Міжбюджетні відносини є важливою складовою бюджетної системи та відображають систему зв'язків між органами влади різних рівнів відносно організації потоків фінансових ресурсів під час горизонтального та вертикального бюджетного вирівнювання. У статті досліджено міжбюджетні відносини в контексті міжбюджетних трансфертів. Зокрема, проведено аналіз динаміки та структури міжбюджетних трансфертів впродовж 2017-2019 рр., досліджено порядок нарахування окремих видів міжбюджетних трансфертів та запропоновано рекомендації щодо подальшої перспективи розвитку та шляхів удосконалення системи міжбюджетних трансфертів. 3 одного боку, надання міжбюджетних трансфертів 3 державного бюджету сприяе фінансуванню заходів соціально-економічного розвитку у належному обсязі та якості в усіх регіонах, з іншого боку, надмірний вплив міжбюджетних трансфертів може ставити місцеву владу в опосередковану залежність від центральних органів державного управління.
\end{abstract}

Ключові слова: місцеві бюджети, бюджетні видатки, міжбюджетні трансферти, субвенції, дотації.

Petyk Lubov, Koren Diana

Lviv Ivan Franko National University

\section{INTERBUDGETARY TRANSFERS AS THE ELEMENT OF INTERBUDGETARY RELATIONS: CURRENT SITUATION AND DEVELOPMENT PROSPECTS}

Summary. Interbudgetary relations are an important component of the budget system, and reflect the system of relations between the authorities at different levels, regarding the organization of flows of financial resources during the horizontal and vertical budgetary alignment. The article examines intergovernmental relations in the context of intergovernmental transfers. In particular, an analysis of the dynamics and structure of intergovernmental transfers during 2017-2019, studied the procedure for calculating certain types of intergovernmental transfers and provided recommendations for further development prospects and ways to improve the system of intergovernmental transfers. On the one hand, the provision of intergovernmental transfers from the state budget contributes to the financing of socio-economic development measures in appropriate volume and quality in all regions, on the other hand, excessive intergovernmental transfers may place local government indirectly dependent on central government. Modern reform of the budget system in the direction of decentralization is accompanied by the transformation of intergovernmental relations. The main tool for regulating intergovernmental relations are intergovernmental transfers. The study of the system of functioning of intergovernmental transfers becomes extremely relevant both from a theoretical and practical point of view in the context of budget decentralization reform. Many scientists have studied the mechanism of intergovernmental transfers in their works, but the problems of reforming the system of intergovernmental transfers in Ukraine, which will ensure the effective functioning of the system of vertical financial equalization; problematic issues related to intergovernmental transfers, which affect the amount of revenues to the budgets of different levels, require further research.The task of the article is to study the system of intergovernmental transfers and budget equalization, analysis of expenditures on intergovernmental transfers during 2017-2019, identification of existing problems and ways to solve them.

Keywords: intergovernmental transfers, subvention, grants, local budgets, expenditures.

$\Pi$ остановка проблеми. Сучасне редормування бюджетної системи в напрямі децентралізації супроводжуеться трансформацією міжбюджетних відносин. Основним інструментом регулювання міжбюджетних відносин $€$ міжбюджетні трансферти. Дослідження системи фрункціонування міжбюджетних трансдертів набуває надзвичайної актуальності як із теоретичного, так і з практичного погляду в умовах проведення реформи бюджетної децентралізації.

Аналіз останніх досліджень і публікацій. Теоретичним та практичним проблемам міжбюджетних трансфертів присвятили свої праці такі вчені: Волохова I.C., Василик О.Д. [6] та Глухова B.I., Далєвська Т.А., Письменний В.В., Простебі Л.І., Федосов В.М. [5] та багато інших. Проте, на нашу думку, практичні аспекти фрункціонування системи міжбюджетних трансфертів потребують подальших досліджень та пошуку шляхів удосконалення.
Виділення невирішених раніше частин загальної проблеми. Багато науковців у своїх працях досліджували механізм міжбюджетних трансфрертів, проте проблеми реформування системи міжбюджетних трансфертів в Україні, що забезпечить ефрективне фрункціонування системи вертикального фрінансового вирівнювання; проблемні питання щодо міжбюджетних трансфертів, які впливають на величину надходжень до бюджетів різних рівнів, потребують подальших досліджень.

Завдання статті полягає у дослідженні системи міжбюджетних трансфертів і бюджетного вирівнювання, аналізу видатків на міжбюджетні трансферти впродовж 2017-2019 рр., визначення існуючих проблем та шляхів їх вирішення.

Виклад основного матеріалу. Відповідно до Бюджетного Кодексу України міжбюджетні відносини - це відносини між державою, Автономною Республікою Крим та територіальними громадами щодо забезпечення відповідних бюд- 
жетів фрінансовими ресурсами, необхідними для виконання фонкщцй, передбачених Конститущією України та законами України. Метою регулювання міжбюджетних відносин є забезпечення відповідності повноважень на здійснення видатків, закріплених законодавчими актами за бюджетами, та фінансових ресурсів, які мають забезпечувати виконання цих повноважень. Інструментом досягнення ціеї мети в тому числі є міжбюджетні трансферти, які забезпечують горизонтальне вирівнювання податкоспроможності територійта фінансування цільових програм. Трансферти можуть надаватись з Державного бюджету України місцевим бюджетам - базова дотація, субвенції на здійснення державних програм соціального захисту, освітня та медична субвенщії, додаткова дотація на компенсацію втрат доходів місцевих бюджетів внаслідок надання пільг, встановлених державою та інші додаткові субвенщії та дотації, визначені статтею 97 Бюджетного Кодексу України. Обсяг таких трансфертів затверджується Державним бюджетом України для кожного місцевого бюджету окремо на відповідних підставах [1].

Непропорційне забезпечення регіонів природними, трудовими, фрінансовими ресурсами регулюється за рахунок базової та реверсної дотацій, спрямованих на горизонтальне вирівнювання податкоспроможності відповідних бюджетів по відношенню до середнього показника. Рівень податкоспроможності бюджету визначається за однойменним індексом і характеризуе співвідношення надходжень податку на прибуток підприемств та податку на доходи фрізичних осіб на одну людину місцевого бюджету до аналогічного середнього показника по всіх місцевих бюджетах України. У випадку, якщо таке співвідношення менше 0,9, то надається базова дотація 3 державного бюджету відповідному місцевому бюджету в обсязі 80 відсотків суми, необхідної для досягнення значення такого індексу забезпеченості. Якщо значення індексу в межах 0,9-1,1 - вирівнювання не здійснюеться, більше 1,1 - передається реверсна дотація 3 відповідного місцевого бюджету до державного в обсязі 50 відсотків суми, що перевищує значення такого індексу [1].

Фінансові взаємовідносини між місцевими бюджетами включають міжбюджетні трансферти у вигляді субвенцій на утримання об'єктів спільного користування чи ліквідащію негативних наслідків діяльності об'єктів спільного користування; субвенцій на виконання інвестиційних проектів, у тому числі на будівництво або реконструкцію об'єктів спільного користування; дотацій та інших субвенцій укладених на основі договору сторін.

Отже, міжбюджетні трансферти - це кошти, які безоплатно і безповоротно передаються 3 державного до місцевого бюджетів та у зворотному напрямі, а також між місцевими бюджетами. До видів міжбюджетних трансфертів належать базова та реверсна дотації, субвенції та додаткові дотації. У табл. 1 продемонстровано виконання державного бюджету в частині міжбюджетних трансфертів за 2017-2019 роки.

Згідно даних табл. 1, сума базової та реверсної дотацій з 2017 по 2019 рр. поступово збільшувалась. Приріст базової дотації в 2019 році склав 78\% порівняно з 2017 роком (4 551,8 млн. грн), а реверсної-75\% (2 919,4 млн. грн). З табл. 1 видно, що видатки за базовою дотацією були вищими, ніж видатки за реверсною, зокрема у 2019 році більш ніж вдвічі. Сума додаткових дотацій змінювалась нерівномірно: у 2018 рощі зростала на 5\% порівняно з 2017 роком та зменшувалась на 8,5\% у 2019 році, при цьому загальний приріст додаткових дотацій у 2019 році по відношенню до 2017 року був від'ємним і склав 4\%. Найбільша частка міжбюджетних трансфертів була виділена на субвенції, максимальна сума яких становила 274234,9 млн. грн у 2018 році і мінімальна - 235 524,7 млн. грн у 2019 році. Динаміка міжбюджетних трансфертів у розрізі їх видів протягом 2017-2019 рр. наведена у рис. 1.

3 рис. 1 бачимо, що впродовж 2017-2019 років частка реверсних дотацій була найменшою, і коливалась від 1 до 2\%, а частка субвенцій найбільшою, і становила $88 \%$ у 2019 році та $91 \%$ у 2017 році. Частка додаткових та базових дотацій коливалась в межах 5-6 \% та 1-4\% відповідно. При цьому в розрізі субвенцій найбільші частки впродовж 2017-2019 рр. становили: освітня, медична, субвенція на допомогу сім'ям 3 дітьми та субвенщія на енергоносії (рис. 2).

3 рис. 2 видно, що в 2017 та 2018 роках структура видатків по субсидіях була схожою, на відміну від 2019 року, де частка субвенцій на енергоносії 3 найбільшої у попередні роки стала найменшою, натомість значно зросла освітня субвенщія. Якщо брати до уваги медичну субвенщію, то у 2018 рощі вона була найвищою за три роки та зменшилась у 2019 році. Субвенщї на допомогу сім'ям з дітыми незначно зростали впродовж 2017-2019 років.

Розглянемо механізм нарахування та розподілу основних видів субвенщій - освітньої та медичної. Освітня субвенція спрямовуеться на оплату праці педагогічних працівників у закладах освіти, перелічених в частині 2 статті 103, Бюджетного кодексу та розподіляеться між відповідними бюджетами на основі формули, яка розробляеться центральним органом виконавчої влади у сфері освіти та затверджується Кабінетом Міністрів України 3 врахуванням кількості учнів закладів загальної середньої освіти, учнів, які здобувають повну загальну середню освіту в закладах профресійної (професійно-технічної) освіти державної та кому-

Таблиця 1

Касові видатки державного бюджету по міжбюджетних трансфертах протягом 2017-2019 рр., млн. грн

\begin{tabular}{|l|c|c|c|c|}
\hline & $\mathbf{2 0 1 7}$ & $\mathbf{2 0 1 8}$ & $\mathbf{2 0 1 9}$ & Приріст 2019/2017, \% \\
\hline Базова дотація & 5815,5 & 8182,7 & 10367,3 & +78 \\
\hline Реверсна дотація & 3895,1 & 5403,9 & 6814,5 & +75 \\
\hline Додаткова дотація & 16183,1 & 16938,4 & 15490,2 & -4 \\
\hline Субвенції & 250943,1 & 274234,9 & 235524,7 & -6 \\
\hline
\end{tabular}

Джерело: розроблено на основі [2] 


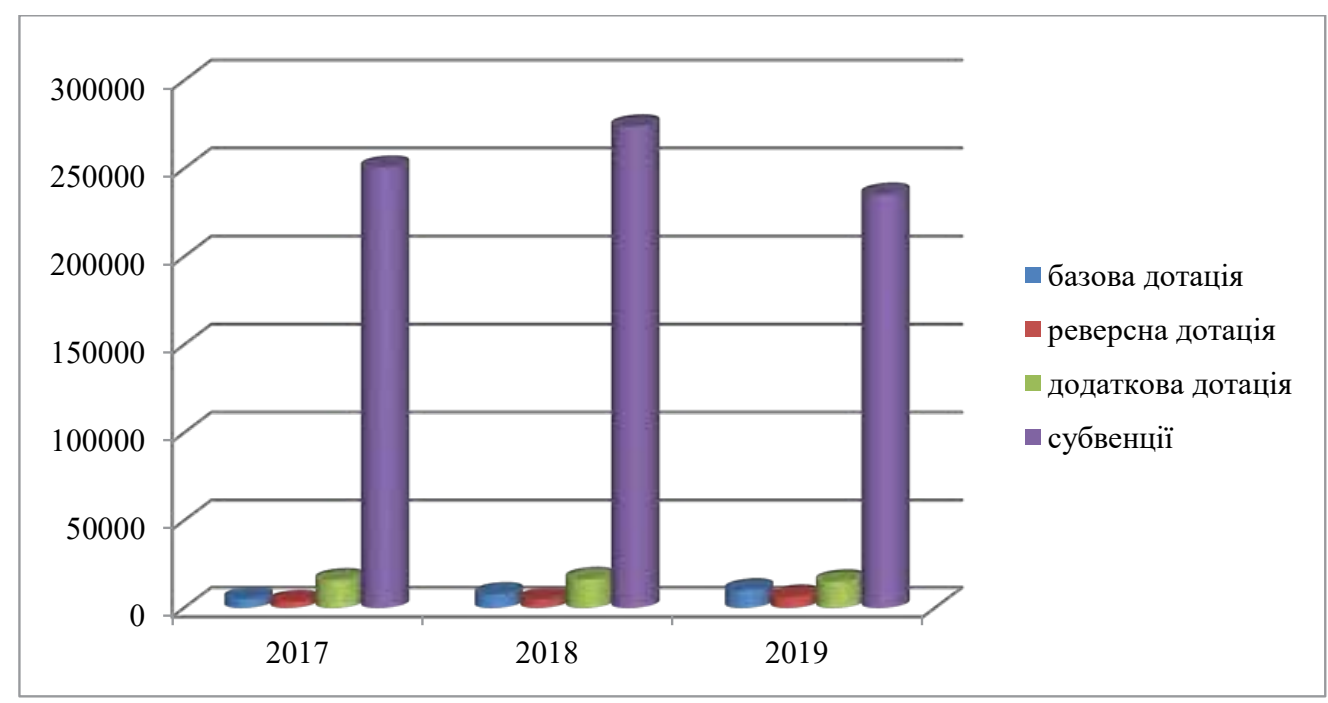

Рис. 1. Касові видатки державного бюджету по ключових видах міжбюджетних трансфертів, 2017-2019 рр., млн. грн

Джерело: розроблено на основі [2]

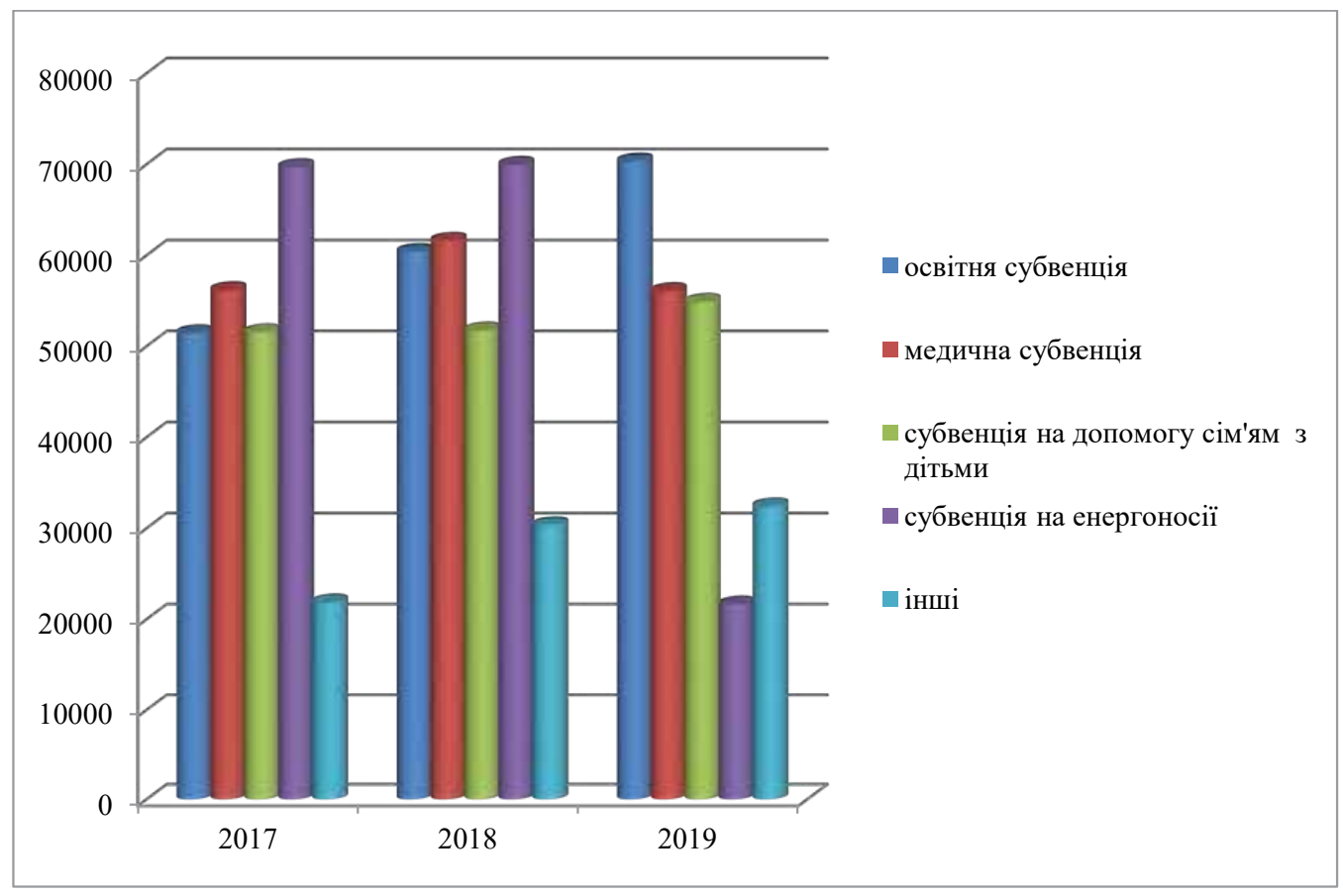

Рис. 2. Динаміка касових видатків державного бюджету по субвенціях протягом 2017-2019 рр., млн. грн

Джерело: розроблено на основі [2]

нальної власності, студентів, які здобувають повну загальну середню освіту в закладах фрахової передвищої освіти і коледжах державної та комунальної власності у міській та сільській місцевості, гірських населених пунктах; розрахункової наповнюваності класів та навчальних планів [3].

Медична субвенщія спрямовуеться на видатки місцевих бюджетів на охорону здоров'я, для оплати поточних видатків, крім видатків на оплату комунальних послуг та енергоносіїв. Розподіл медичної субвенщіі здійснюеться на основі формули визначеної Постановою Кабміну № 618 від 19.08.2015 p. iз врахуванням наступних параметрів: кількості населення відповідної адміністративно-територі- альної одинищі; коригуючих коефіцієнтів, що враховують відмінності у вартості надання медичної допомоги; особливостей надання медичної допомоги у гірських населених пунктах [4].

Міжбюджетні трансферти 3 рахунків державного бюджету перераховуються органами Казначейства України бюджету Автономної Республіки Крим, обласним бюджетам, бюджетам міст Києва і Севастополя, іншим бюджетам місцевого самоврядування, для яких у державному бюджеті визначаються міжбюджетні трансферти.

Порядок перерахування міжбюджетних трансфертів 3 державного бюджету місцевим бюджетам, реверсної дотації, а також порядок 
перерахування міжбюджетних трансдертів між місцевими бюджетами визначаються Кабінетом Міністрів України і мають забезпечувати своєчасність, рівномірність, гарантованість та повноту перерахування трансорертів.

Відповідно до розпису Державного бюджету України, органами Казначейства України здійснюеться перерахування базової дотації та реверсної дотащії щодекадно, освітньої і медичної субвенцій - двічі на місяць, а субвенції на надання державної підтримки особам з особливими освітніми потребами - один раз на місяць [1].

Проведений аналіз сучасного стану міжбюджетних трансорертів як складової міжбюджетних відносин свідчить про те, що система фрінансового вирівнювання, яка діє в Україні, є досить недосконалою, оскільки не створює необхідної зацікавленості місцевих органів влади в пошуку і мобілізації резервів зростання доходів та раціонального використання коштів в результаті чого, реверсні дотащії становлять лише 1-2\% загальної суми міжбюджетних трансрертів. Тобто, надходження 3 місцевих бюджетів, податкоспроможність яких вища за нормативний коефіціент, в умовах чинної системи бюджетного регулювання є мізерними, натомість частка видатків на міжбюджетні трансферти 3 державного бюджету становить основну частину. На наш погляд, необхідно створити такий механізм міжбюджетних відносин, який буде основою едрективності бюджетів усіх рівнів у частині забезпечення добробуту населення. Задля вирішення проблем у сфрері міжбюджетних трансфертів, на нашу думку, слід внести наступні зміни:

- удосконалення нормативно-правової бази, що в перспективі розширить повноваження органів місцевого самоврядування, зокрема в частині фінансування;
- відмови від безцільових трансорертів та переходу до системи цільових трансорертів, що дозволить контролювати використання коштів державних фрондів, які передаються до місцевих бюджетів. Прив'язка фрінансування до конкретних завдань дозволить чітко відслідковувати напрями та ефективність використання переданих коштів; розширення фінансової бази органів місцевого самоврядування дозволить спростити та прискорити рух грошових коштів на місцях.

Висновки і пропозиції. Отже, організація вітчизняної системи міжбюджетних відносин характеризуеться такими недоліками: значним ступенем залежності місцевих бюджетів від державного бюджету; нерівномірним співвідношенням між дотаціями та субвенщіями у структурі трансорертів; умовністю процесу віднесення одних адміністративно-територіальних одинищ до складу реципієнтів, а інших до донорів. Основною проблемою міжбюджетних відносин у частині міжбюджетних трансфертів залишається залежність місцевих бюджетів від державного бюджету, що стосується, зокрема, видатків на обслуговування освітньої, медичної та соціальної сорери. Збілышення податкових надходжень місцевих бюджетів за діючим механізмом не спонукає їх до діяльності, оскільки ці кошти в подальшому будуть передані з метою горизонтального вирівнювання податкоспроможності відповідних бюджетів. Тому для зниження рівня фрінансової залежності місцевих бюджетів потрібно забезпечити формування доходів місцевих бюджетів 3 урахуванням територіальної приналежності податків. Проблему контролю за цільовим використанням переданих з Державного бюджету України коштів у структурі трансдертів можна вирішити за рахунок зростання частки субвенщій як цільових коштів, використання яких спрямоване на фрінансування конкретних об’єктів.

\section{Список літератури:}

1. Бюджетний кодекс України // Верховна Рада України. 2010. URL: https://zakon.rada.gov.ua/laws/show/245617\#n1439 (дата звернення: 30.11.2020).

2. Державна казначейська служба України. Міжбюджетні трансферти. URL:https://www.treasury.gov.ua/ua/ kaznachejstvo-informuye/mizhbyudzhetni-transferti (дата звернення: 30.11.2020).

3. Постанова «Про затвердження формули розподілу освітньої субвенції між місцевими бюджетами» № 1088 // Кабінет Міністрів України. 27.12.2017. URL: https://zakon.rada.gov.ua/laws/show/1088-2017-\%D0\%BF\#Text (дата звернення: 30.11.2020).

4. Постанова «Про затвердження формули розподілу обсягу медичної субвенції з державного бюджету місцевим бюджетам» № 618// Кабінет Міністрів України. 19.08.2015. URL: https://zakon.rada.gov.ua/laws/show/6182015-\%D0\%BF\#Text (дата звернення: 30.11.2020).

5. Федосов В.М., Юрій С.І. Теорія фрінансів : підручник. Київ : ЦУЛ, 2010. 450 с.

6. Василик О.Д., Павлюк К.В. Бюджетна система України : підручник. Київ : ЦНЛ, 2004.544 с.

7. Ситник Н.С., Стасишин А.В., Західна О.Р., Петик Л.О. та ін. Фінанси об'єднаних територіальних громад : навчальний посібник / за заг. ред. Н.С. Ситник. Львів : ЛНУ імені Івана Франка, 2019. 536 с.

\section{References:}

1. Biudzhetnyi kodeks Ukrainy no 2456 // Verkhovna Rada Ukrainy. 2010. St. 572. URL: https://zakon.rada.gov.ua/ laws/show/2456-17\#n1439 (accessed 30.11.2020).

2. Derzhavna kaznacheiska sluzhba Ukrainy. Mizhbiudzhetni transferty [Intergovernmental transfers]. URL: https://www.treasury.gov.ua/ua/kaznachejstvo-informuye/mizhbyudzhetni-transferti (accessed 30.11.2020).

3. Postanova Pro zatverdzhennia formuly rozpodilu osvitnoi subventsii mizh mistsevymy biudzhetamy [About the statement of the formula of distribution of the educational subvention between local budgets] no. 1088 // Kabinet Ministriv Ukrainy. 27.12.2017. URL: https://zakon.rada.gov.ua/laws/show/1088-2017-\%D0\%BF\#Text (accessed 30.11.2020).

4. Postanova Pro zatverdzhennia formuly rozpodilu obsiahu medychnoi subventsii z derzhavnoho biudzhetu mistsevym biudzhetam [About the statement of the formula of distribution of volume of medical subvention from the state budget to local budgets] no. 618// Kabinet Ministriv Ukrainy. 19.08.2015. URL: https://zakon.rada.gov.ua/ laws/show/618-2015-\%D0\%BF\#Text (accessed 30.11.2020).

5. Fedosov V.M., Yurii S.I. (2010) Teoriia finansiv [Theory of finance]. Kyiv: TsUL, $450 \mathrm{p}$.

6. Vasylyk O.D., Pavliuk K.V. (2004) Biudzhetna systema Ukrainy [Budget system of Ukraine]. Kyiv: TsNL, 544 p.

7. Sytnyk N.S., Stasyshyn A.V., Zakhidna O.R., Petyk L.O. ta in. (2019) Finansy obiednanykh terytorialnykh hromad: navchalnyi posibnyk [Finances of united territorial communities]. Lviv: LNU imeni Ivana Franka, 536 p. 